\title{
Co-Movements of European Equity Markets Before and After the 1987 Crash*
}

\author{
Ilhan Meric \\ Rider University, U.S.A. \\ Gulser Meric \\ Rowan University, U.S.A.
}

This article studies the changes in the co-movements of the twelve largest European equity markets after the 1987 international equity market crash. Tests based on Box M and principal component analysis indicate that the comovements of these equity markets changed significantly after the crash. Low correlations among national equity markets are often presented as evidence in support of the benefits of international portfolio diversification. The findings indicate that correlations among the twelve largest European equity markets and between these equity markets and the U.S. equity market increased substantially; therefore, the benefits of international diversification with these twelve European equity markets decreased considerably after the crash (JEL G15).

Key words: correlation of returns, Box M analysis, European equity markets co-movements, principal component analysis.

\section{Introduction}

Low correlations among national equity markets are often presented as evidence in support of the benefits of international portfolio diversification, e.g., Levy and Sarnat (1970), Solnik (1974), Watson (1978), Meric and Meric (1989), and DeFusco, Geppert and Tsetsekos (1996). However, articles by Roll (1988), Goodhart (1988), King and Wadhwani (1990), Hamao, Masulis, and Ng (1990), and Malliaris and Urrutia (1992) document a significant increase in correlations between

\footnotetext{
* The authors would like to thank the editors and two anonymous reviewers for their helpful comments and suggestions.
}

(Multinational Finance Journal, 1997, vol. 1, no. 2, pp. 137-152)

(C) by Multinational Finance Society, a nonprofit corporation. All rights reserved. DOI: $10.17578 / 1-2-4$ 
national equity market co-movements during, and several months after, the 1987 international equity market crash.

The articles by Arshanapalli and Doukas (1993) (henceforth A-D), Lau and McInish (1993) (henceforth L-M), and Lee and Kim (1993) (henceforth L-K) determine that close co-movements between national equity markets continued 2-3 years after the crash. However, these articles cover a relatively short time period after the crash (A-D through May 1990, L-M through December 1989, and L-K through December 1990). Whether the long-term co-movements of national equity markets changed significantly after the crash has not been investigated in previous articles. The objective of this article is to study the long-term co-movements of European and U.S. equity markets before and after the international equity market crash of October 1987. Our study covers a 76-month period after the crash, thus it permits us to determine if the changes in the co-movements of national equity markets after the crash are long-term changes.

The A-D, L-M, and L-K articles cover a short time period after the crash, A-D and L-M use daily data and L-K use weekly data to have a sufficient number of observations for their statistical tests. Previous articles investigating the long-term co-movements of national equity markets generally use monthly returns data. ${ }^{1}$ In this article, we also use monthly data to study the long-term co-movements of European and U.S. equity markets before and after the 1987 crash. $^{2}$

A-D, L-M, and L-K study the co-movements of equity markets from different parts of the world. ${ }^{3}$ In this article, we focus on the comovements of European equity markets. Although a number of articles dealing with the co-movements of the world's equity markets are available, articles focusing solely on European equity markets are virtually non-existent. We also include the U.S. equity market in the study to be able to evaluate the changes in the portfolio diversification benefits for the U.S.-based investor after the crash.

In this article, we use a different methodology than that used in the

1. See Ripley (1973), Lessard (1974 and 1976), Sharma and Kennedy (1977), Haney and Lloyd (1978), Watson (1980), Maldonado and Saunders (1981), Philippatos, Christofi, and Christofi (1983), Meric and Meric (1989 and 1996), and Kasa (1995).

2. Since studying the effect of different holding periods is not an objective of this study, only monthly data are used. The studies mentioned in Footnote \#1 also use only monthly data.

3. The A-D study covers three European, Japanese, and U.S. equity markets. The L-M study covers six European, two Asian, Australian, and U.S. equity markets. The L-K study covers seven European, three Asian, and two North American equity markets. 
A-D, L-M, and L-K studies. A-D use co-integration analysis to compare the time-series linkages between the world's largest equity markets before and after the crash. In this article, we focus on the contemporaneous correlation structure of returns with an aim toward evaluating the changes in international diversification benefits after the 1987 crash. L-M use Box's M statistics and L-K use factor analysis to compare the co-movements of international equity markets before and after the crash. In this article, we use both Box's M methodology and factor analysis to study the changes in the long-term co-movements of national equity markets.

Unlike the A-D, L-M and L-K articles which only compare the precrash and post-crash periods, we study the long-term stability of national equity market relationships before the crash to show that, although the long-term co-movements of the markets changed significantly after the crash, there was long-term stability in the relationships before the crash.

This article is organized as follows: Section II describes our data and methodology. Section III compares the correlation coefficients and volatilities of the U.S. and twelve European equity markets before and after the 1987 crash. In Section IV, Box's M statistic is used to study the inter-temporal stability of the correlation matrix of equity market index returns before and after the crash. In Section V, principal component analysis is used to study the degree of harmony among the co-movements of the U.S. and twelve European equity markets before and after the crash. Our findings are summarized and conclusions are presented in Section VI.

\section{Data and Methodology}

The constant-dollar monthly equity market index returns used in the study are taken from Morgan Stanley Capital International Perspective (MSCIP) publications. The MSCIP index returns are published for the following twelve European countries since 1973: Austria, Belgium, Denmark, France, Germany, Italy, the Netherlands, Norway, Spain, Sweden, Switzerland and the United Kingdom. Our study covers all twelve of these European equity markets. The U.S. index returns are also obtained from the MSCIP publications. The combined market capitalization of the companies included in the MSCIP indices represents approximately sixty percent of the total market value of all 
stocks traded in the equity markets of these countries.

We first use correlation analysis to compare the co-movements of the equity markets in the pre- and post-crash periods. Since all equity markets experienced unusually large swings during the crash month of October 1987, this month is excluded from the sample. Since we use 76 monthly observations for the post-crash period (November 1987February 1994), the comparison is made with the 76-month period preceding the international equity market crash (June 1981-September 1987). The coefficient of variation of equity market index returns (i.e., standard deviation divided by mean return) is used to compare the volatilities of the markets before and after the crash. Box's $M$ is a standard test statistic used in the multiple discriminant analysis (MDA) and multivariate analysis of variance (MANOVA) computer programs to test the equality of the variance-covariance or correlation matrices of different groups of observations. Box's M statistic is used in this study to test the hypothesis that the equity market index return correlation matrices of the 76-month period before the crash (Period II) and the 76month period after the crash (Period III) are significantly different.

TABLE 1. Time Periods Covered in the Study

\begin{tabular}{lr}
\hline Period I & February 1975-May 1981 \\
Period II & June 1981-September 1987 \\
Period III & November 1987-February 1994 \\
\hline
\end{tabular}

Note: All periods include 76 months. The market crash month of October 1987 is excluded from the data.

To demonstrate that, although the co-movements of the markets changed significantly after the crash, they had long-term stability before the crash, Box's $M$ statistic is also used to test the equality of the correlation matrices of the 76-month period immediately before the crash (Period II) and the 76-month period preceding Period II (February 1975-May 1981, Period I).

If the null hypothesis of equal correlation matrices for $q$ groups of observations is true, then Box's M-statistic is given by

$$
M=\phi \sum_{i=1}^{q}\left(n_{i}-1\right) \ln \left|C_{i}^{-1} C\right|
$$

where 


$$
\begin{gathered}
C=\frac{1}{N-q} \sum_{i=1}^{q}\left(n_{i}-1\right) C_{i}, \\
\phi=1-\frac{2 p^{2}+3 p-1}{6(p+1)(q-1)} \sum_{i=1}^{q} \frac{1}{\left(n_{i}-1\right)(N-q)},
\end{gathered}
$$

$n_{i}$ is the number of observations for the $i^{\text {th }}$ group in the sample, $C_{i}$ is a $p \times p$ correlation matrix for the $i^{\text {th }}$ group, and $N$ is the sum of observations for the $q$ groups. The statistic $C$ has a $\chi^{2}$ distribution with $p(p+1)(q-1) / 2$ degrees of freedom. ${ }^{4}$

Principal component analysis is used to determine the degree of harmony in the co-movements of the markets before and after the crash. ${ }^{5}$ The monthly stock market index returns are used as input for the SPSSX-PCA computer program to obtain the principal components. To eliminate first-order serial correlation which could result in spurious inferences about the causes of equity market co-movements, principal component analysis is applied to the log-returns. The number of statistically significant principal components is determined by using Kaiser's significance rule. That is, principal components with eigenvalues greater than one are considered to be statistically significant.

Consider a set of variables (i.e., equity markets) $X_{1}, X_{2}, \ldots, X_{p}$ measured on $N$ observational units (i.e., monthly returns). Assume that the variables can be put together to form a linear combination:

$$
Y_{1}=\alpha_{1}^{(1)} X_{1}+\alpha_{2}^{(1)} X_{2}+\cdots+\alpha_{p}^{(1)} X_{p}
$$

which is referred to as the first principal component of the $p$ variables. The coefficients of $A_{1}^{\prime}=\left[\alpha_{1}^{(1)}, \alpha_{2}^{(1)}, \ldots, \alpha_{p}^{(1)}\right]$ are selected so as to maximize the variance of $Y_{1}$

$$
\operatorname{var}\left(Y_{1}\right)=A_{1}^{\prime} \Sigma_{x x} A_{1}
$$

4. For a detailed discussion of Box's M methodology, see Mardia, Kent, and Bibby (1979), Cho and Taylor (1987), and Meric and Meric (1989).

5. For a detailed discussion of the principal component method, see: Marascuilo and Levin (1983). 
The $A_{p}$ can be determined from the sample variance-covariance matrix $\Sigma_{x x}$ by solving the following characteristic equation:

$$
\left|\Sigma_{x x}-\lambda I\right|=0
$$

This equation has $p$ ordered roots, the eigenvalues:

$$
\lambda_{1} \geq \lambda_{2} \geq \ldots \geq \lambda_{p} \geq 0
$$

where $\lambda_{i}$, for $i=1,2, \ldots, p$. The sum of the eigenvalues is

$$
\lambda_{1}+\lambda_{2}+\cdots+\lambda_{p}=p
$$

so that the variance explained by the first principal component is given by $\lambda_{1} / p$. The variance explained by the second principal component is given by $\lambda_{2} / p$, etc. With Kaiser's significance rule, $n$ principal components are significant so that

$$
\lambda_{1} \geq \lambda_{2} \geq \cdots \geq \lambda_{n} \geq 1
$$

\section{Correlation Analysis}

The matrix of correlation coefficients between the thirteen equity markets in the 76-month period immediately before the crash (Period II) and in the 76-month period after the crash (Period III) is presented in table 2. For comparison, the correlation coefficients for the 76-month period before the crash are shown in the lower diagonal-half of the matrix and the correlation coefficients for the 76-month period after the crash are shown in the upper diagonal-half of the matrix. The figures in the table show that the correlation coefficients are substantially higher in the post-crash period than in the pre-crash period. Seventy of the 78 correlation coefficients are higher in the post-crash period than in the pre-crash period.

The most closely correlated and the least closely correlated equity markets in the 76-month pre-crash and post-crash periods are presented in table 3. The correlation coefficients for both the most closely correlated and the least closely correlated equity markets are considerably higher in the post-crash period than in the pre-crash period. 
TABLE 2. The Correlation Matrix of National Equity Market Index Returns

\begin{tabular}{lccccccccccccc}
\hline & Aus & Bel & Den & Fra & Ger & Ita & Net & Nor & Spa & Swe & Swi & U.K. U.S. \\
Aus & & .31 & .35 & .47 & .66 & .38 & .52 & .42 & .41 & .33 & .45 & .43 & .14 \\
Bel & .37 & & .54 & .70 & .67 & .37 & .64 & .42 & .44 & .39 & .53 & .45 & .44 \\
Den & .15 & .41 & & .50 & .59 & .46 & .55 & .46 & .56 & .51 & .56 & .52 & .27 \\
Fra & .42 & .56 & .37 & & .78 & .39 & .67 & .44 & .51 & .44 & .61 & .54 & .44 \\
Ger & .51 & .47 & .37 & .48 & & .52 & .75 & .50 & .47 & .49 & .64 & .55 & .36 \\
Ita & .29 & .47 & .24 & .58 & .36 & & .40 & .38 & .50 & .44 & .41 & .34 & .16 \\
Net & .27 & .46 & .43 & .45 & .56 & .38 & & .61 & .54 & .57 & .73 & .77 & .57 \\
Nor & .14 & .40 & .38 & .40 & .28 & .16 & .49 & & .42 & .60 & .45 & .60 & .46 \\
Spa & .23 & .34 & .22 & .46 & .31 & .42 & .30 & .21 & & .67 & .49 & .58 & .37 \\
Swe & .20 & .30 & .21 & .28 & .29 & .40 & .32 & .41 & .26 & & .57 & .62 & .50 \\
Swi & .48 & .51 & .46 & .50 & .73 & .35 & .61 & .44 & .32 & .42 & & .69 & .51 \\
U.K. & .21 & .47 & .32 & .45 & .33 & .33 & .58 & .47 & .34 & .42 & .48 & & .61 \\
U.S. & .04 & .29 & .36 & .35 & .21 & .22 & .52 & .39 & .19 & .22 & .42 & .45 & \\
\hline
\end{tabular}

Note: The lower diagonal-half of the matrix shows the correlation coefficients for the 76-month period before the October-1987 crash and the upper diagonal-half of the matrix shows the correlation coefficients for the 76-month period after the crash.

TABLE 3. Most Closely and Least Closely Correlated Equity Markets

76-Month Period Before the Crash

Correlation

Equity Markets Coefficient

A. Most Correlated

Germany-Switzerland

Netherlands-Switzerland

France-Italy

Netherlands-U.K.

Belgium-France

Germany-Netherlands

B. Least Correlated

Austria-U.S.

Austria-Norway

Austria-Denmark

Italy-Norway

Spain-U.S.

Austria-Sweden
76-Month Period After the Crash

\begin{tabular}{ll} 
Cquity Markets & Coefficion \\
\hline
\end{tabular}

France-Germany $\quad .78$

Netherlands-U.K. $\quad .77$

Germany-Netherlands $\quad .75$

Netherlands-Switzerland $\quad .73$

Belgium-France $\quad .70$

Switzerland-U.K. $\quad .69$

Austria-U.S. $\quad .14$

Italy-U.S. $\quad .16$

Denmark-U.S. $\quad .27$

Austria-Belgium $\quad .31$

Austria-Sweden $\quad .33$

Austria-Denmark $\quad .35$

The correlation coefficients of the U.S. equity market with the twelve European equity markets before and after the October 1987 stock market crash are shown in table 4. 
TABLE 4. Correlations of U.S. Equity Market with European Equity Markets

\begin{tabular}{lccc}
\hline Equity Market & $\begin{array}{c}\text { 76-Month Period } \\
\text { Before the Crash }\end{array}$ & $\begin{array}{l}\text { 76-Month Period } \\
\text { After the Crash }\end{array}$ & $\begin{array}{c}\text { Percentage } \\
\text { Change (\%) }\end{array}$ \\
\hline Netherlands & .52 & .57 & 9.6 \\
U.K. & .45 & .61 & 35.6 \\
Switzerland & .42 & .51 & 21.4 \\
Norway & .39 & .46 & 17.9 \\
Denmark & .36 & .27 & -25.0 \\
France & .35 & .44 & 25.7 \\
Belgium & .29 & .44 & 51.7 \\
Sweden & .22 & .50 & 127.3 \\
Italy & .22 & .16 & -27.3 \\
Germany & .21 & .36 & 71.4 \\
Spain & .19 & .37 & 94.7 \\
Austria & .04 & .14 & 250.0 \\
Average (all markets) & .31 & .40 & 29.0 \\
\hline
\end{tabular}

The figures in the table indicate that the correlation of the U.S. equity market with the twelve European equity markets increased substantially from the pre-crash period to the post-crash period. All correlation coefficients but the correlation coefficients with the Danish and Italian equity markets increased considerably from the pre-crash period to the post-crash period. The average correlation coefficient of the U.S. equity market with the twelve European equity markets increased from .31 in the pre-crash period to .4 in the post-crash period, an increase of 29 percent. ${ }^{6}$ This increase in the correlation of the U.S. equity market with the European equity markets implies a decrease in international diversification benefits to U.S.-based investors with the European equity markets after the crash.

The average correlation coefficients of each equity market with the other equity markets for the 76-month pre-crash and post-crash periods are presented in table 5. For comparison, average correlation coefficients for the twelve European equity markets and for all thirteen equity markets are shown, separately. The figures in the table indicate that the average correlation coefficients of all equity markets increased substantially from the pre-crash period to the post-crash period.

6. The average correlation coefficient before the crash is .305 without rounding. The average correlation coefficient after the crash is .4025 without rounding. The exact increase with unrounded average correlation coefficient figures is 31.97 percent. 
TABLE 5. Average Correlation Coefficients

\begin{tabular}{|c|c|c|c|c|c|c|}
\hline \multirow[b]{2}{*}{ Equity Market } & \multicolumn{2}{|c|}{$\begin{array}{l}\text { 76-Month Period } \\
\text { Before the Crash }\end{array}$} & \multicolumn{2}{|c|}{$\begin{array}{l}\text { 76-Month Period } \\
\text { After the Crash }\end{array}$} & \multicolumn{2}{|c|}{ Percentage Change } \\
\hline & $\begin{array}{l}\text { Only } \\
\text { European } \\
\text { Markets }\end{array}$ & $\begin{array}{l}\text { All } \\
\text { Markets }\end{array}$ & $\begin{array}{l}\text { Only } \\
\text { European } \\
\text { Markets }\end{array}$ & $\begin{array}{l}\text { All } \\
\text { Markets }\end{array}$ & $\begin{array}{l}\text { Only } \\
\text { European } \\
\text { Markets }\end{array}$ & $\begin{array}{l}\text { All } \\
\text { Markets }\end{array}$ \\
\hline Switzerland & .48 & .47 & .56 & .55 & 16.7 & 17.0 \\
\hline France & .45 & .44 & .55 & .54 & 22.2 & 22.7 \\
\hline Belgium & .43 & .42 & .50 & .49 & 16.3 & 16.7 \\
\hline Netherlands & .43 & .45 & .43 & .61 & 41.9 & 35.6 \\
\hline Germany & .43 & .41 & .60 & .58 & 39.5 & 41.5 \\
\hline U.K. & .40 & .40 & .55 & .55 & 37.5 & 37.5 \\
\hline Italy & .36 & .35 & .42 & .40 & 16.7 & 14.3 \\
\hline Norway & .34 & .35 & .48 & .48 & 41.2 & 37.1 \\
\hline Denmark & .33 & .33 & .51 & .49 & 54.6 & 48.5 \\
\hline Sweden & .32 & .31 & .51 & .51 & 59.4 & 64.5 \\
\hline U.S. & & .31 & & .40 & & 29.0 \\
\hline Spain & .31 & .30 & .51 & .50 & 64.5 & 66.7 \\
\hline Austria & .30 & .28 & .43 & .41 & 43.3 & 46.4 \\
\hline Average & .38 & .37 & .52 & .50 & 36.8 & 35.1 \\
\hline
\end{tabular}

The average correlation coefficient for all thirteen equity markets increased from .37 in the pre-crash period to .5 in the post-crash period, an increase of 35.1 percent. The average correlation coefficient for the twelve European equity markets increased from .38 in the pre-crash period to .52 in the post-crash period, an increase of 36.8 percent. These statistics show that the co-movements of the thirteen equity markets have become much more harmonious in the post-crash period when compared with the pre-crash period. These findings also indicate a substantial decrease in portfolio diversification benefits with European equity markets for international investors after the 1987 crash.

The coefficient of variation figures of the thirteen equity markets for the 76-month pre-crash and post-crash periods are presented in table 6.The figures in the table indicate that the volatilities of the markets increased substantially from the pre-crash period to the post-crash period. The average coefficient of variation for all thirteen equity markets increased from 3.71 in the pre-crash period to 7.86 in the postcrash period, an increase of about 111.9 percent. This suggests that, as an average, the thirteen equity markets are more than twice as volatile in the post-crash period than they were in the pre-crash period. 
Although the volatilities of all the other equity markets increased considerably from the pre-crash period to the post-crash period, the volatility of the Danish equity market somewhat decreased in the postcrash period compared with the pre-crash period. The volatility of the Spanish equity market almost quadrupled in the post-crash period compared with the pre-crash period.

TABLE 6. Volatility of the Equity Markets

\begin{tabular}{lccr}
\hline & \multicolumn{2}{c}{ Coefficient of Variation of Index Returns } & \\
\cline { 2 - 3 } Equity Markets & $\begin{array}{l}\text { 76-Month Period } \\
\text { Before the Crash }\end{array}$ & $\begin{array}{l}\text { 76-Month Period } \\
\text { After the Crash }\end{array}$ & $\begin{array}{c}\text { Percentage } \\
\text { Change (\%) }\end{array}$ \\
\hline Sweden & 2.85 & 7.01 & 146.0 \\
Netherlands & 2.71 & 4.61 & 70.1 \\
Belgium & 2.74 & 6.29 & 129.6 \\
Switzerland & 2.96 & 4.56 & 54.1 \\
France & 3.07 & 5.68 & 85.0 \\
Germany & 3.34 & 7.39 & 121.3 \\
U.S. & 3.44 & 4.78 & 38.6 \\
U.K. & 3.73 & 8.96 & 140.2 \\
Norway & 3.87 & 8.74 & 125.8 \\
Austria & 4.25 & 6.19 & 45.7 \\
Spain & 4.42 & 20.41 & 361.7 \\
Denmark & 5.34 & 4.59 & -14.0 \\
Italy & 5.56 & 12.97 & 133.3 \\
Average & 3.71 & 7.86 & 111.9 \\
\hline
\end{tabular}

Although the volatilities of the equity markets increased considerably from the pre-crash period to the post-crash period, correlations between them also increased substantially from the precrash period to the post-crash period. This implies that the markets have become more responsive to volatilities in the other markets after the crash because only volatilities in the same direction would cause high positive correlations between the markets.

\section{Inter-Temporal Stability of the Correlation Matrix}

In this section of the article, we first test the hypothesis that the correlation matrix of the markets for the 76-month period after the crash 
(Period III) is significantly different from the correlation matrix for the 76-month period before the crash (Period II). Box's M statistics, the Fratio equivalents of these statistics, and the p-values showing the significance levels of these statistics are presented in table 7. For comparison, the tests are applied to the twelve European equity markets and all thirteen equity markets, separately.

TABLE 7. Box's M Test for the Equality of Correlation Matrices

\begin{tabular}{lrrrrrrrr}
\hline & \multicolumn{3}{c}{ Only European Markets } & & \multicolumn{3}{l}{ All Markets } \\
\cline { 2 - 3 } \cline { 7 - 8 } Time Periods & Box's M & F-Value & P-Value & & Box's M & F-Value & P-Value \\
\hline Period I vs. Period II & 91.29 & 1.07 & .31 & & 98.49 & .98 & .52 \\
Period II vs. Period III & 110.84 & 1.30 & .04 & & 120.84 & 1.20 & .09 \\
\hline
\end{tabular}

Note: The F-values follow the F-distribution with $(78,71,051)$ degrees of freedom.

The test statistics in the table show that the correlation matrix of the twelve European equity markets for the 76-month period after the crash is significantly different from the correlation matrix for the 76-month period before the crash at the conventional five-percent level. The test statistics also show that the correlation matrix of all thirteen equity markets for the 76-month period after the crash is different from the correlation matrix for the 76-month period before the crash only at a nine-percent significance level.

To demonstrate that the long-term co-movements of the markets had stability before the crash, we also compare the correlation matrix of the 76-month period immediately before the crash (Period II) with the correlation matrix of the 76-month period preceding Period II (i.e., the correlation matrix of Period I). These results are also presented in table 7. The test statistics in the table show that the correlation matrices of Periods I and II are not significantly different. This indicates that there was inter-temporal stability in the long-term co-movements of the markets before the crash.

A comparison of the $\mathrm{p}$-values for the pre-crash and post-crash intertemporal stability tests indicates that the correlation structure of equity market index returns changed substantially from the pre-crash period to the post-crash period. The p-value is .31 in the pre-crash test with the twelve European equity markets compared with only .04 in the postcrash test. The p-value is .52 in the pre-crash test with all thirteen equity markets compared with only .09 in the post-crash test. 


\section{Statistically Significant Principal Components}

In this section of the article, we use principal component analysis to determine the number of statistically significant principal components in Periods I, II, and III. Since a detailed analysis of the co-movement patterns of the markets is not an objective of the article, the factor loadings of individual equity markets are not given. The number of statistically significant principal components in each time period (i.e., principal components with eigenvalues greater than one) and the percentage variance explained by the first principal component in each time period are presented in table 8 . For comparison, the number of statistically significant principal components with the twelve European equity markets and with all thirteen equity markets are shown, separately.

TABLE 8. Statistically Significant Principal Components

\begin{tabular}{|c|c|c|c|c|}
\hline \multirow[b]{2}{*}{ Time Periods } & \multicolumn{2}{|c|}{$\begin{array}{l}\text { Number of Significant } \\
\text { Principal Components }\end{array}$} & \multicolumn{2}{|c|}{$\begin{array}{l}\text { Percentage of Variance } \\
\text { Explained by the First } \\
\text { Principal Component }\end{array}$} \\
\hline & $\begin{array}{l}\text { Only } \\
\text { European } \\
\text { Markets }\end{array}$ & $\begin{array}{l}\text { All } \\
\text { Markets }\end{array}$ & $\begin{array}{l}\text { Only } \\
\text { European } \\
\text { Markets }\end{array}$ & $\begin{array}{l}\text { All } \\
\text { Markets }\end{array}$ \\
\hline Period I & 3 & 3 & 43.9 & 61.1 \\
\hline Period II & 3 & 3 & 42.9 & 59.7 \\
\hline Period III & 1 & 2 & 55.3 & 61.7 \\
\hline
\end{tabular}

Although there are three statistically significant principal components with both samples in Periods I and II, there is only one statistically significant principal component with the European sample and only two statistically significant principal components with the complete sample in Period III . This shows that the co-movements of the markets are much more harmonious in Period III than they were in Periods I and II. With both samples, the first principal component, the most important principal component, can explain a greater percentage of the total variation in the index returns in Period III when compared with Periods I and II. This also indicates a greater degree of harmony in the co-movements of the markets in Period III when compared with Periods I and II. Like the correlation analysis results, the principal 
component analysis results also suggest that the co-movements of the markets have become much more harmonious after the crash. ${ }^{7}$

\section{Summary and Conclusions}

Low correlations among national equity markets are often presented as evidence in support of the benefits of international portfolio diversification. Our findings in this study indicate that correlations among the twelve largest European equity markets and between these equity markets and the U.S. equity market increased substantially; therefore, the benefits of international portfolio diversification with these European equity markets decreased considerably after the 1987 international equity market crash.

IMF Balance of Payments Statistics (1996) indicate that in 1989 there was $\$ 47.4$ billion equity portfolio outflow from the twelve European countries covered in this study and $\$ 58.8$ billion equity portfolio inflow to these countries, a net equity portfolio inflow of $\$ 11.4$ billion. However, in 1994 these twelve European countries had \$56.2 billion equity portfolio outflow and only $\$ 44.1$ billion equity portfolio inflow, a net equity portfolio outflow of $\$ 12.1$ billion. ${ }^{8}$

Previous studies show that low correlation between emerging equity markets and between developed equity markets and emerging equity markets make emerging equity markets excellent prospects for international diversification. ${ }^{9}$ IMF Balance of Payments Statistics (1996) indicate that net equity portfolio inflow to emerging equity markets increased from $\$ 1.5$ billion in 1989 to $\$ 16.9$ billion in 1994 . In a Wall Street Journal panel discussion, top U.S. international mutual fund managers indicate that an increasing portion of U.S. foreign equity portfolios is invested in emerging equity markets in recent years for

7. Theodossiou et al. (1997) explore the time-varying behavior of the correlation of U.S., U.K., and Japanese equity returns during the 1984-1994 period by using the Kalman filter statistical technique within a multivariate GARCH model. They conclude that the contemporaneous correlations of returns in the three markets are not time-varying. They argue that increased co-movements in the stock indices that are observed after market corrections are due to changes in the covariance structure of returns rather than the correlation structure.

8. It is possible that some international equity portfolio investments flowing to nonEuropean equity markets may be seeking higher returns as well as better diversification.

9. See DeFusco, Geppert, and Tsetsekos (1996), Ratner, and Leal (1996), Divecha, Drach, and Stefek (1992), Harvey (1995), and Aggarwal and Leal (1996). 
diversification purposes. ${ }^{10}$

In three previous studies, Arshanapalli and Doukas (A-D) (1993), Lau and McInish (L-M) (1993), and Lee and Kim (L-K)(1993) show that the co-movements of national equity markets changed significantly after the 1987 crash. However, these studies cover a relatively short time period after the crash. Our study extends the A-D, L-M, and L-K studies by focusing on U.S. and European equity markets and by covering a longer time period after the crash. Our findings with Box's $M$ tests show that there was inter-temporal stability in the long-term comovements of U.S. and European equity markets before the crash. However, this long-term stability changed significantly after the crash. Our correlation analysis and principal component analysis results indicate that the co-movements of U.S. and European equity markets have become closer after the crash reducing portfolio benefits.

\section{References}

Aggarwal, R., and Leal, R. 1996. Linkages and volatility in emerging capital markets. In G. Tsetsekos and M. Papaioannou, eds., Portfolio Management and Hedging Strategies for Emerging Capital Markets. Chicago: Irwin.

Arshanapalli, B., and Doukas, J. 1993. International stock market linkages: Evidence from the pre- and post-October 1987 period. Journal of Banking and Finance 17 (January): 193-208.

Cho, D. C., and Taylor, W. M. 1987. The seasonal stability of the factor structure of stock returns. Journal of Finance 42 (December): 1195-1211.

DeFusco, R. A.; Geppert, J. M.; and Tsetsekos, G. P. 1996. Long-run diversification potential in emerging stock markets. Financial Review 31 (May): 343-363.

Divecha, A. B.; Drach, J.; and Stefek, D. 1992. Emerging markets: A quantitative perspective. Journal of Portfolio Management 19 (Fall): $41-50$.

Goodhart, C. A. E. 1988. The international transmission of asset price volatility. In Financial Market Volatility. Kansas City, Kansas: Federal Reserve Bank of Kansas City.

Hamao, Y.; Masulis, R.; and Ng, V. 1990. Correlations in price changes and volatility across international stock markets. Review of Financial Studies 3 (Spring): 281-308.

Haney, Jr., R. L., and Lloyd, W. P. 1978. An examination of the stability of the

10. See: Wall Street Journal supplement, "A Century of Investing: The Global View," a panel discussion of top U.S. international fund managers, May 28, 1996, pp. R53-R55. 
intertemporal relationships among national stock market indices. Nebraska Journal of Economics and Business (Spring): 55-65.

Harvey, C. R. 1995. Predictable risk and returns in emerging markets. Review of Financial Studies 8 (Fall): 773-816.

International Monetary Fund, 1996. Balance of Payments Statistics.

Kasa, K. 1995. Co-movements among national stock markets. Economic Review (1). San Francisco, California: Federal Reserve Bank of San Francisco.

King, M., and Wadhwani, S. 1990. Transmission of volatility between stock markets. Review of Financial Studies 3 (Spring): 5-33.

Lau, S. T., and McInish, T. H. 1993. Co-movements of international equity returns: A comparison of the pre- and post-October 19, 1987, periods. Global Finance Journal 4 (Fall): 1-19.

Lee, S. B., and Kim, K. J. 1993. Does the October 1987 crash strengthen the co-movements among national stock markets. Review of Financial Economics 3 (Fall): 89-102.

Lessard, D. R. 1974. World, national, and industry factors in equity returns. Journal of Finance 29 (May): 379-391.

Lessard, D. R. 1976. International diversification. Financial Analysts Journal 32 (January-February): 32-38.

Levy, H., and Sarnat, M. 1970. International diversification of investment portfolios. American Economic Review 60 (September): 668-675.

Maldonado, R., and Saunders, A. 1981. International portfolio diversification and the inter-temporal stability of international stock market relationships, 1957-1978. Financial Management 10 (Autumn): 54-63.

Malliaris, A. G., and Urrutia, J. L. 1992. The international crash of October 1987: Causality tests. Journal of Financial and Quantitative Analysis 27 (September): 353-364.

Marascuilo, L. A., and Levin, J. R. 1983. Multivariate Statistics in Social Sciences: A Researcher's Guide. Monterey, California: Brooks/Cole Publishing Company.

Mardia, K.; Kent, J.; and Bibby, J. 1979. Multivariate Analysis. New York: Academy Press.

Meric, I., and Meric, G. 1989. Potential gains from international portfolio diversification and inter-temporal stability and seasonality in international stock market relationships. Journal of Banking and Finance 13 (September): 627-640.

Meric, I., and Meric, G. 1996. Inter-temporal stability in the long-term comovements of the world's stock markets. Journal of Multinational Financial Management 6 (4): 73-83.

Philippatos, G. C.; Christofi, A.; and Christofi, P. 1983. The inter-temporal stability of international stock market relationships: Another view. Financial Management 12 (Winter): 63-69.

Ratner, M., and Leal, R. 1996. Causality tests for the emerging markets of Latin 
America. Journal of Emerging Markets 1 (Spring): 29-40.

Ripley, D. M. 1973. Systematic elements in the linkage of national stock market indices. Review of Economics and Statistics 55 (August): 356-361.

Roll, R. W. 1988. The international crash of October 1987. Financial Analysts Journal 44 (September/October): 19-35.

Sharma, J. L., and Kennedy, R. E. 1977. A comparative analysis of stock price behavior on the Bombay, London and New York stock exchanges. Journal of Financial and Quantitative Analysis 12 (September): 391-413.

Solnik, B. H. 1974. Why not diversify internationally? Financial Analysts Journal 30 (July/August): 48-54.

Theodossiou, P.; Kahya, E.; Koutmos, G.; and Christofi, A. 1997. Volatility reversion and correlation structure of returns in major international stock markets. Financial Review 32 (May): 205-224.

Wall Street Journal supplement. 1996. A century of investing: The global view (a panel discussion of top international fund managers) (May 28): R53-R55.

Watson, J. 1978. A study of possible gains from international investment. Journal of Business Finance and Accounting 5 (Summer): 195-206.

Watson, J. 1980. The stationarity of inter-country correlation coefficients: A note. Journal of Business Finance and Accounting 7 (Summer): 297-304. 